\title{
The Complex Relational Dynamics in Public Sector Reforms
}

Ilpo Laitinen

City of Helsinki, Finland

Inga Nyholm

Ministry of Finance, Finland

\section{Jari Stenvall}

University of Tampere, Finland

Jari Kaivo-oja

University of Turku, Finland

$\Gamma$ Cross $h$ ttp://dx.doi.org/10.5755/j01.eis.0.9.12795

Even though public sector reforms have become nearly every day-business in many countries, the implementation of the reforms is often a challenge for change management. This is the case also in Finland. Nationwide local government reform aiming to create a thriving municipal structure was launched in 2011 and gained a lot attention and criticism. We aim to analyze what kind of diverse views occurred in the implementation phase of this particular reform and how those affected the reform process. Thus we aim to analyse the reform as a complex social process by using the figuration theory of Elias'. According to our analysis it seems that there is a dominant discourse that includes actors with different goals. We also identified counter discourse, arisen as a reaction to the dominant discourse. In the reforms there also seems to be some structural diversity due to actors who look at things from various perspectives. Thus the implementation of reforms is not only a question of the policy goals but also a question of different actors competing with each others. This underlines the fact that managing public sector reforms should focus more on building long-term processes of co-operation and not only on institutional or rationally explained changes.

KEYWORDS: public sector reform, policy implementation, complexity, figuration theory, change management.

Public sector reforms have become everyday business. Reforms are seen in this context as conscious rearrangements to address the changes in the environment and the resulting demands for corrections (e.g. Caiden 1969; Pollitt \& Bouckaert 2004; Collin \& Robertson 2005; Brunsson 2009; Bouckaert 2009). The planned reforms have often been extensive aimed for instance, an overall reform in regional administration.

In many cases, public sector reforms have often been politically significant but differently acknowledged. In general reforms often aim e.g. to re-allocate resources, to adjust the proportion of government in the GDP, to redefine responsibilities of different actors and to solve low level performance of public services (Bouckaert 2009). The state of public economics is an essential motive for public sector reforms in many western countries, as well in Finland.

Yet the benefits of reforms - even the economical ones -are often questioned and especially the rationally implemented reformism criticized (Drechsler 2013; Hanes \& Wikström 2006; Bouckaert \& Halligan 2008; Thorne \& Kouzmin 2012). This illustrates that the implementation of reforms is often complex and ambiguous (e.g. Haveri 2006; Brunsson 2009; Sandersson 2000; Fimgreite \& Laegreid 2009; Valler, Wood \& North 2000; Drechsler 2013; Boivard 2009): various views and opinions occur which often requires effective change - or reform management.

In this paper we analyse government reforms as complex social processes and from the perspec-

\section{EIS 9/2015}

The Complex Relational Dynamics in Public Sector Reforms

Submitted 04/2015

Accepted for publication 07/2015

\section{Abstract}

\section{Introduction}

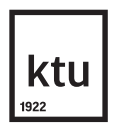

European Integration Studies No. 9 / 2015 pp. 53-59

DOI 10.5755/j01.eis.0.9.12795

(c) Kaunas University of Technology 


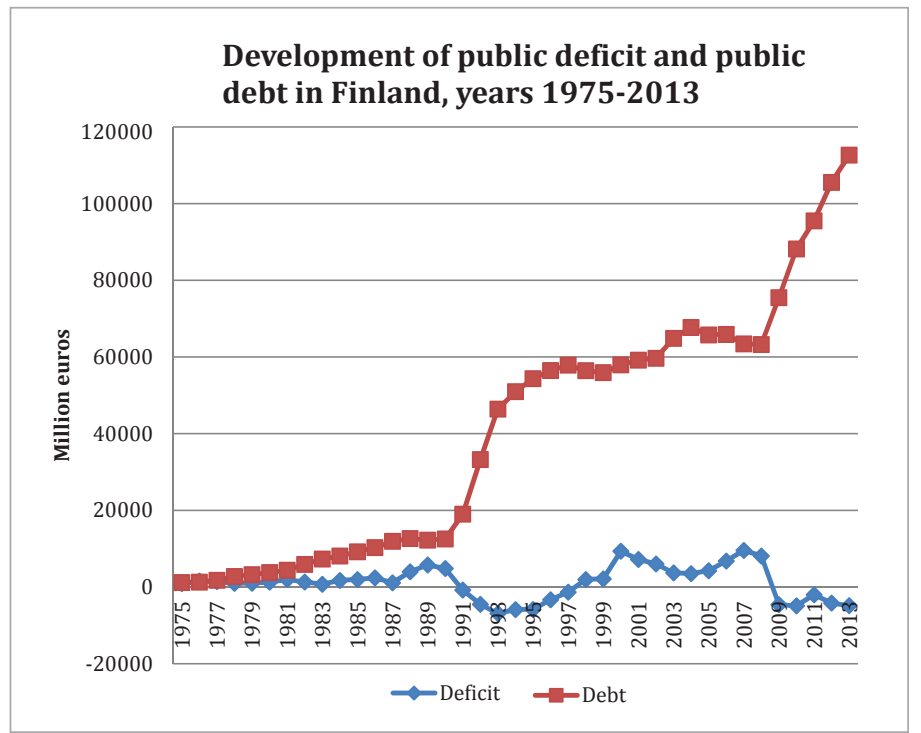

tive of change management. Our aim is to gain more theoretical and empirical understanding on the reform processes as changes as well as the various social factors affecting them.

We concentrate on a nationwide local government reform in Finland launched by the previous government on 2011. The aim of the reform was to create a thriving municipal structure (Government programme 2011). It has been claimed that Finnish government reforms are often approached from a rational perspective both in research and in practice. This particular reform has gained both a lot public attention and criticism, but most importantly the implementation has strongly divided different stakeholders. Thus it serves as a good empirical example for the purposes of our paper.

We examine the research topic from the perspective of various actors in aiming to create a picture of the reform as a social process. Our data consists of statements of municipalities (total $24 \mathrm{mu}-$ nicipalities, two statements from each) from two different regions (Greater Helsinki region, Tampere city region). Beside we use the official material drawn up by the government and parliament (reports, protocols, government proposals) and material produced by media or other actors such as researchers (e.g. articles, opinion writings). The total number of analysed documents is about sixty $(\mathrm{N}=60)$. On the basis of the material we aim firstly to represent the diverse views of different actors and secondly to contemplate a reliable description of the discourses existing in the implementation phase of the local government reform. By doing this we are thirdly able to illustrate social factors creating complexity in the public sector reforms. We have used qualitative content analysis aiming to note central themes and discourses and building a logical chain of evidence and in formulating our conclusions (see Kvale 1996; Miles \& Huberman 1994; Silverman 1993). Our analysis is also partly based on participatory interpretation as we have been involved in the reform as, for instance, evaluators, preparers and consulted experts. This involvement in the discussions enables us to interpret the various opinions and in the data material.

Theory of figurations

It is possible to argue that complexity theory is focused on making films of how phenomena - like public sector reform - develop under a variety of influences (Teisman \& Klijn 2008, 288). In our article we understand the concept of complexity as a metaphor. In this viewpoint metaphors help to understand the reality differently compared to traditional approach which means that the reality is seen as mechanistic and systematic machine. The reality is seen as emergent, dynamic and nonlinear.

We emphasize the importance of social process as the source of complexity (Stacey 2001, 2010; Macmillan 2009; Marion 2008). Our theoretical framework is based on Norbert Elias' (2001) literature and referred to as process sociology. Elias put lots of emphasis on the dynamics of relationships between people and on the dynamics of the process (see Elias 2001; Wouters 2009). Social processes connected with figuration can be unplanned and can have a structure of their own. Dynamic of the figuration has novel, emerging outcomes. 
Elias uses the term figuration to refer to 'interdependency networks'. The pattern independent human beings as groups or individuals form with each other can be described with the concept of figuration. (Elias 1987, 85; Elias 2001b:149; van Krieken, 1998, 55-65; Bloyce \& Murphy 2007.)

Figuration is 'a structure of mutually oriented and dependent people and agents'. In the context of public administration reform, individuals and agencies - like political parties, ministries, local governments and the reformers of administration - are engaged in many interactions and power relations. (Eg. Gentilcore 1999; May 2004; Powell 2010.)

According to Elias structures are figurations constituted by acting human beings (van Krieken, $1998,59)$. In the figurational theory, the central propositions are that 1) all humans are interdependent, 2) these interdependencies form emergent dynamics, 3) these emergent dynamics are figurations in flux, changing and constantly transforming, 4) these figurations are in long-term unpredicted and unplanned and 5) knowledge develops within these figurations. (Eg. Mennell, 1998, 251-252; Goudsblom \& Mennell, 1998, 130-131; Quilley \& Loyal, 2004, 5.)

In this article we concentrate on the figuration concerning the local government reform. We assume that the reform interconnects independent people and organizations. Our aim is to clarify why figuration explains as a mechanism the contents of public sector reforms. We are specifying on the basis of our data and the discourse related to the reform, which factors are sources of social complexity in the implementation of reforms.

Municipalities in Finland have a central and autonomous status as in many other Nordic countries. They are self-governed and have strong independency, with taxing power. They also organise the main welfare services, e.g. social and health care services. Especially during recent years, many municipalities have had difficulties in arranging the services due to e.g. financial constraints, growing service demand, decreasing workforce and aging population. In addition, the municipal structure seems not to be very cohesive and not ideally suited to promote e.g. industrial and business activity.

Due to these changes a local government reform was launched by previousGovernment after the parliamentary elections in 2011. Government aimed to tackle the problems with reforming municipal structure alongside with the reforms related to the division of tasks between the state and municipalities, reform of Local Government Act and e.g. the reform of the state subsidy system. The objective of the local government reform was to create a thriving municipal structure built on economically robust municipalities consisting of customary commuter areas large enough to provide main basic public services. Municipalities should have been capable of conducting successful policies in business and industry, development strategies and in preventing urban sprawl. (Government programme 2011.)

The reform and its progress was afterwards outlined by the government in many conjunctions. Several responses to interpellations and a statement on the reform was given in the parliament in the government period 2011-2015. Also municipalities were asked to give their statements in different phases, e.g. to different reports, legislation proposals or surveys made by the government. The reform was implemented by a special legislation, Local Government Structure Act, that came in force on $1^{\text {st }}$ of July 2013.

As mentioned above, the reform has gained a lot public attention. The mechanisms (mainly mergers except in the metropolitan area) and implementation strongly divide different actors, municipalities, parties, politicians and other interest groups, and also researchers. These diverse opinions can be illustrated through the cases and our data material. 


\section{Sources of complexity in municipal reform}

Farce, botch, and mess are among the words used to characterize the reform. The reform has also been criticized for "walking blindfolded" and claimed to cause chaos in municipalities. Thus, complexity and diversity can be identified in the discourse on local government reform.

Complexity can manifest itself in various ways in reforms. We relate it to the premises, the implementation process, and the definition of contents and need. The premises are environmental factors that affect the conceptualisation of the reform. Beside complexity can connect to the implementation process, to the concrete steps a process is planned as well as to the proceeding and steering of a reform. It can also have a connection with the definition of the reform. It seems that in this case, the contents and purpose have not been clear for all the actors, while others have shared them and some opposed them. It is also possible that a "wicked problem" occurs (Cf. Rittel \& Webber 1973) meaning several different solutions and perspectives existing simultaneously. In this case it seems obvious that different actors have seen different mechanisms (mergers or cooperation) suitable. The problem has however been, that only one (merger) was included in the reform "tool-box" of the government.

Connections to other reforms, and information basis that is closely connected to diverse opinions, are premise factors. The latter ones produce complexity especially when several truths are in question. In public administration, there are connections between reforms, and the solutions made or not made in one may affect another (eg. Bouckaert 2009). The factor related to the social process and causing complexity is power games. When there are dissimilar interests, power games envelopes the different actors' ambitions to steer the reform in the desired direction. For instance, issues can be unpredictably taken up for strategic reasons related to power games. This can happen both at the local level and in central government and is not easy to verify. The complexity in the implementation process is connected to, for instance, by whom and in what way the reform is taken forwards. Problems are caused due to unclear or not approved reasons of implementation or ontents. These all together illustrate that reform as a whole is viewed from various angles. It makes the overall picture of the reform polyphonic and thus it may appear blurred for many actors. In a social process, different factors are linked together in a complex and unique way.

One of the problems in the development of public administration in Finland has been the constant implementation of separate partial reforms (Nyholm \& Airaksinen 2011). The reforms have affected a single sector of administration at a time, such as regional, municipal, or provincial administration. Operations have not always been coordinated.

A central factor in the local government reform causing complexity has been seen to be its relation to simultaneous reforms. Such reforms include e.g. the earlier municipal and service structure reform (2005-2012), the reform of social and health care sector and the renewal of the state subsidy system. The unclear question has been to what extent is the reform based on the earlier reforms and how it is connected to the other simultaneous reforms like the reform of social and health care.

Ralph Stacey (2010) has paid attention to the power games related to social interaction. The idea is that in interactive relationships different actors try to affect one another, which in itself tends to create complexity. This can take place in a variety of ways, such as invalidation or forming allies with other parties. (Stacey 2010; see also Gentilcore 1999; May 2004; Powell 2010.) Power games seem to explain most of the complexity related to reforms. In conjunction to the local government reform, power games started almost instantly after the government publicized its' program. Opposing the reform has actually become one of the central political issues in current government period.

Literature on change management contains much discussion on how successful changes should have a clear direction and a defined need (e.g. Stenvall et al. 2009). The direction involved in contents has a connection to what kind of public administration is desired through the reform. The need is attached to the substantial justifications of the reform. Defining the direction emerges in conjunction to the reform as an unclear problem. There have even been discussions on whether the reform has a steering perspective or not. 
The change process in reforms is related to the leadership: who and by what kind of means is leading and implementing the work. Literature on change management has actually repeatedly paid attention to the fact that if there is unclarity e.g. in the manner of implementation, succeeding becomes more difficult.

The opinions of whether the Finnish reform as a process lacks clarity diverse. According to some experts, municipalities have not been given an overall view of the reform process. Some actors have also criticised that the change process is not open enough. When also criticism on whether all important views have been considered in conjunction to the preparation has been expressed, the reform has faced unpredicted opposition as different operators have tried to have an effect on the reform.

On the basis of our data, the approach of figuration theory shows its explanatory power. The analysis has shown that the complexity of public sector reform can be analyzed by Elias' figuration theory. This means that we need research on the factors that create complexity in public sector reform. From the basis of our analysis, we recognize the following theses on the complexity of reforms.

\section{Thesis I. Complexity arises the question of the dominant discourse}

We identified that the figuration of reform contains so called dominant discourse. It includes not only the reform in favor of the proposals and their justification but also the actors who support the proposal.

The dominant discourse is not necessarily unanimous. It includes actors with different goals. The actors have reached a consensus that the reform must be made, and this is justified because of certain arguments. In this sense, even within the dominant discourse may be struggles and power games that can change unexpectedly in the substance of the reform. We recognize the logic of collaboration and competition (see Stacey 2001) within dominant discourse for instance between political parties. A counter discourse has risen as a reaction to the dominant discourse. That counter discourse could question unpredictable ways for instance the notion of merger and scale benefits. Respectively the interests of the actors may be put into question, or even a social network that constitutes the dominant discourse.

This finding has analogies to the study "How networks explain unintended policy implementation outcomes" (Grantham 2001). Grantham concluded, that implementation of policies is not only a question of how the policy changes, but also a question of the agencies for different actors not willing to fit into same ideals, different actors competing with each other and actors who remain out of the core.

Thesis II. Structures, activities, environment, knowledge base, and publicity create diversity which further creates complexity in public sector reforms

The structural diversity means that there are actors in the figuration, who look at things from different perspectives. The diversity covers all activities related to the reform such as the political decision-making and human resource management at local level. The diversity of environment relates to the fact that the reform affects a number of factors, such as the other reforms or public services. The knowledge base of diversity occurs when the reform can be interpreted in numerous perspectives. The diversity of publicity includes the fact that the debate is taking place also in various arenas, for example in the research community, in the press or as a part of administrative processes.

This aforementioned finding comes close to those studies which found tensions between explicit and implicit steering. Explicit refers to formal mission and implicit to informal mission including various demands, different needs, and historical context.

In Elias' figurational process the division was between established and outsiders. The authority 
of forming municipalities has been in the hands of the established status. Despite of the formal power differencies, the process has been figurational and included both formal and informal practices. Figuration refers to negotiations, hearing procedures where involved have been seen as a phase to reach the wished outcome. Figuration refers also to processes where the power actually does not lie in the center or in the hands of established, but brings forth all kinds of opposing maneuvers from the communities and groups of local interdependencies in order to manipulate the wished outcome to their own advantage.

What is noteworthy is that the process is not linear. It contains lots of variation and diversity. It also has been a real process by its nature; meaning that there is no a static, final stage, but the powerbalance has been in flux: formal has caused both formal and informal counter reactions. Diversity means that due to the complexity in points of views it is difficult to predict what kind of things, by whom, and in what context are debated in different phases of the reform process. Diversified opinions and our results underline that a reform as a change requires long-term process of co-operation instead of purely institutional or rationally explained or implemented changes (see OECD 2015).

The figurational process of the whole Finnish local government reform can be divided to three different parties' relational dynamics. Those parties were the early adapters, opposing forces and the vast majority who have been puzzled. The latter group was seeking deeper understanding of the problem in order to create real, novel ideas to solve those. But understanding and even rationalities which in the first place were motivating the whole reform, were by-passed at the same time when the first two groups, parties were locked into their opinions. Thus the flexibility in the change process ended up to be rigid installation between different actors. Following the logic of figurational processes based on powerbalances do not bring out the final outcome or solution, especially if the third group, party is left voiceless.

\section{References}

Bouckaert, G. (2009) Public Sector Reform in Central and Eastern Europe, Halduskultuur, 2009, vol 10, 94-104.

Bouckaert, G., Halligan, J. (2008) Managing Performance. International Comparisons. London: Routledge.

Boivard, T. (2008) Emergent Strategic Management and Planning Mechanism in Complex Adaptive Systems. Public Management Review, 10; 3, 319-340. http://dx.doi.org/10.1080/14719030802002741

Brunsson, N. (2009) Reform as Routine: Organizational Change in the Modern World. Oxford University Press. Oxford.

Caiden, G. (1969) Administrative Reform. Aldine, Chicago.

Collin, J-P., Robertson, M. (2005) The Borough system of consolidated Montréal: revisiting urban governance in a composite metropolis, Journal of Urban Affairs, Vol. 27, Number 3, 307-330. http://dx.doi.org/10.1111/ j.0735-2166.2005.00238.x

Drechsler, W. (2013) Coercive Municipal Amalgamation Today - With Illustrations from Estonia, Halduskultuur - Administrative Culture 14 (1), 158-165.

Elias, N. (2001) The Society of Individuals, The Continuum International Publishing Group Inc., New York.

Fimgreite, A.L., Laegreid, P. (2009) Reorganizing the welfare state Administration. Partnership, networks and accountability. Public Management Review, 11; 3, 281 297. http://dx.doi.org/10.1080/14719030902798198

Government programme (2011) Prime minister Jyrki Katainen government's programme (2011-2015).

Grantham, A. (2001) How Networks Explain Unintended Policy Implementation Outcomes: The Case of UK Rail Privatization, Public Administration, Vol. 79, No. 4, 2001, 851-870. http://dx.doi.org/10.1111/14679299.00283

Hanes, N.,Wikström, M. (2006) Does the Local Government Structure Affect Population and Income Growth? An Empirical Analysis of the 1952 Municipal Reform in Sweden, Regional Studies, Vol. 42.4, 593-604. http:// dx.doi.org/10.1080/00343400701281311

Haveri, A (2006) Complexity in Local Government Change: Limits to Rational Reform. Public Management Review. Vol 8. http://dx.doi. org/10.1080/14719030500518667

Kvale S. (1996), InterViews, An Introduction to Qualitative Research Interviewing, Sage, Thousand Oaks

Marion, R. (2008) Complexity Theory for organizations and Organizational Leadership, In Ulh-Bien, M., Marion, R. (ed.) Complexity Leadership, Information Age Publishing, North Caroline. 
McMillan, E. (2004) Complexity, Organizations and Change - An Essential Introduction, Routledge, London. http://dx.doi.org/10.4324/9780203507124

Miles, M.B. \& Huberman A.M. (1994), An Expanded Sourcebook Qualitative Data Analysis, second edition, Sage, Thousand Oaks

Nyholm, I., Airaksinen, J. (2009) Muutoksen monet ulottuvuudet. Miten tutkia muutosta kuntakontekstissa. Kunnallistieteellinen aikakauskirja 37 (3), 236-255.

OECD (2015) Governing the City. OECD Publishing.

Pollitt, C., Bouckaert, G. (2000) Public Management Reform: A Comparative Analysis. Oxford; Oxford University Press.

Rittel, H., Webber, M. (1973) „Dilemmas in a General Theory of Planning, Policy Sciences, Vol. 4, Elsevier Scientific Publishing Company, Inc., Amsterdam, 1973. (Reprinted in Cross, N (ed.), Developments in Design Methodology, J. Wiley \& Sons, Chichester 1984), 155-169.

Sandersson, I (2000) Evaluation in Complex Policy System. Evaluation 6, 433-454. http://dx.doi. org/10.1177/13563890022209415

Silverman D. (1993), Interpreting Qualitative Data, Methods for Analyzing Talk, Text and Interaction, Sage, London

Stacey, R. (2001) Complex Responsive Processes in Organizations, Routledge, London.
Stacey, R. (2010). Complexity and Organizational Reality - Uncertainty and the need to rethink management after the collapse of investment capitalism, $2^{\text {nd }}$ edition, Abingdon, Oxon; Routledge.

Stenvall, J., Vakkala, H., Syväjärvi, A., Leinonen, J., Juntunen, P., Oulasvirta, L., Tiilikainen, L. (2009) Parasta nyt - Kunta-ja palvelurakenneuudistuksen toimeenpanon suunnitteluvaiheen loppuraportti. Valtiovarainministeriön julkaisuja 11/2009. Helsinki.

Teisman, T., Klijn, E-H. (2008) Complexity Theory and Public Management. In introduction.

Thorne, K., Kouzmin, A. (2012), Reform, Revolution, or Mission Impossible? Radicalizing a Public Administration of Post the Global Financial Crisis, Administrative. Theory \& Praxis, March 2012, Vol. 34, No 1, 16-39.

Valler, D., Wood, A., North, P. (2000) Local governance and local business interests: a critical review, Progress in Human Geography 24,3, 409-428. http://dx.doi. org/10.1191/030913200701540492

Wouters, C. (2008) How civilizing processes continued: towards an informalization of manners and a third nature personality. In Gabriel, N. and Mennell, S. (ed) Norbert Elias and Figurational Research: Processual Thinking in Sociology, Sociological Review Monographs series 7, Wiley-Blackwell/The Sociological Review, 140-159.

\section{ILPO LAITINEN \\ Dr. Sc. Director of Administration}

City of Helsinki, Finland

\section{Address}

Tel. +358401549690

E-mail:

ilpo.laitinen@hel.fi

\section{INGA NYHOLM \\ Dr. Sc. (Admin.) Ministerial adviser \\ Ministry of Finance, Finland}

Address

Tel. +358401549690

E-mail: Finland.inga. nyholm@vm.fi

\section{JARI STENVALL}

Professor

Administrative

Sciences, University of Tampere, Finland

\section{Address}

Tel. +358408284350

E-mail:

jari.stenvall@uta.fi
JARI KAIVO-OJA

Research Director

University of Turku,

Finland

Address

Tel. +358417530244

E-mail:

jari.kaivo-oja@utu.fi
About the authors 